\title{
HADDAD, Sérgio, $O$ Educador: um perfil de Paulo Freire. São Paulo: Todavia, 2019. 251 páginas.
}

\author{
Leandro Aparecido de Oliveira Teófilo \\ Graduado em Ciências Jurídicas e Sociais pela Universidade Camilo Castelo Branco. \\ Especializado em Direito Civil pela Escola Paulista da Magistratura. \\ Aluno especial do curso de Pós-Graduação Stricto Sensu em Educação, oferecido pela \\ Universidade Nove de Julho (Uninove). \\ teofilo2009@gmail.com
}

\section{Para citar- (ABNT NBR 6023:2018)}

TEÓFILO, Leandro Aparecido de Oliveira. Resenha. Eccos - Revista Cientifica, São Paulo, n. 55 p. 1-3, e18365, out./dez., 2020. Resenha da obra de HADDAD, Sérgio, O Educador: um perfil de Paulo Freire. São Paulo: Todavia, 2019, 251 páginas. https://doi.org/10.5585/eccos.n55.18365.

Com simplicidade e delicadeza, Sérgio Haddad apresenta, a seus leitores, um perfil biográfico de Paulo Freire.

Nascido em 1949, em São Paulo, Sérgio Haddad, o autor da obra em destaque, é doutor em história e filosofia da educação pela Universidade de São Paulo (USP). Foi presidente da Associação Brasileira de Organizações Não-Governamentais e do Fundo Brasil de Direitos Humanos. Participou da Comissão Nacional de Alfabetização e Educação de Jovens e Adultos, além de ter integrado o Conselho Técnico-Científico da Educação Básica da Capes. Classificado como pesquisador nível A pelo CNPq, atualmente coordena projetos especiais da Ação Educativa e atua como docente na Universidade de Caxias do Sul. O currículo lattes de Sergio Haddad revela a trajetória acadêmica de um pesquisador extremamente qualificado, com inúmeros projetos e publicações científicas. A educação de jovens e adultos é tema recorrente em seus trabalhos, o que justifica sua afinidade com as ideias e pensamentos de Paulo Freire.

O livro, ora resenhado, é despretensioso e de fácil compreensão, pois oferece ao seu leitor um material acessível em conteúdo e forma, de modo a permitir que os principais fatos da vida e obra de Paulo Freire atinjam o grande público. A proposta é compatível com o que há de mais fundamental do pensamento de Paulo Freire, educador popular, que priorizava o diálogo com a grande massa, especialmente com as camadas mais vulneráveis da sociedade.

Segundo Sergio Haddad, o livro foi idealizado e passou a ser construído em agosto de 2017, quando notou que a sociedade brasileira estava dividida e que o nome de Paulo Freire havia sido conduzido ao centro de um debate público. Os argumentos utilizados para defendêlo ou atacá-lo, no entanto, eram repletos de desinformação. Seria importante, naquele momento, 
produzir algo que fornecesse elementos claros sobre a vida e obra de Paulo Freire, de modo a ampliar a qualidade do debate. Era necessário trazer sobriedade às discussões contaminadas pela polarização ideológica.

Muitas aflições e questionamentos surgiram durante a elaboração da obra em análise. $\mathrm{O}$ autor considerava um grande desafio situar o seu trabalho em meio a tantos e tão importantes estudos realizados sobre Paulo Freire. Contudo, ao longo do tempo, percebeu que nunca é demais escrever acerca de Paulo Freire: sempre há o que ser dito, sempre há novas visões e interpretações, uma vez que Paulo Freire é um personagem riquíssimo e, segundo o autor, cada vez mais debatido no Brasil e no mundo.

Considerado um livro biográfico, a obra é dividida em treze capítulos, com títulos sugestivos que aguçam a curiosidade do leitor. A proposta é refazer o percurso de Paulo Freire sem aderir à disputa ideológica e, ao mesmo tempo, revelar as múltiplas facetas de um intelectual complexo e decisivo para a cultura brasileira. Os títulos dos capítulos foram escolhidos de forma acurada e merecem destaque. Por um lado, revelam a criatividade do autor da obra e, por outro, entusiasmam seus leitores. Dentre os títulos mais criativos convém destacar o capítulo quatro, denominado "Uma enorme lata de Nescau", e o capítulo oito, intitulado "Uma caixa de Sonho de Valsa”, que tratam de fatos curiosos e relevantes da vida de Paulo Freire.

Durante a leitura, é possível refletir sobre diversas experiências e situações vivenciadas por Paulo Freire, como sua prisão no Quartel de Obuses, no bairro de Jatobá, em Olinda. Na época, Freire foi encarcerado, durante determinado tempo, em uma das solitárias do referido quartel: “... a cela era pequena, as paredes ásperas; havia apenas uma cama e altura justa para que Paulo ficasse de pé” (p. 22). Como se vê, o cuidado ao descrever minuciosamente os fatos auxilia o leitor na visualização dos cenários, personagens e acontecimentos narrados no livro.

Além da prisão, o autor narra o exílio, a fama internacional, as vivências na África, a volta ao Brasil após a anistia, a retomada da carreira acadêmica e a experiência de Paulo Freire como secretário municipal de educação em São Paulo. O livro também apresenta coletânea de fotografias, o que facilita a visualização dos fatos descritos na obra.

As concepções e ideias centrais de Paulo Freire são apresentadas de forma leve e didática ao longo da narrativa, a fim de propiciar sua rápida compreensão pelo leitor. O livro é, sem dúvida, destinado a público diversificado, visto que não se apresenta sob a forma acadêmica, nem excessivamente sob o prisma do rigor científico. Ao contrário, o estilo simples de redação torna a leitura da obra extremamente agradável e, em consequência, permite que a narrativa ultrapasse os muros das universidades e ingresse nas residências do grande público. 
O livro também ilumina aspectos pouco conhecidos da vida de Paulo Freire, como o fato dele nunca ter se declarado comunista ou pregado a educação partidária nas escolas.

A dinâmica dos círculos de cultura e os desafios para a implementação do método de alfabetização freiriano também são tratados no livro.

Sergio Haddad destaca que "Paulo projetava os Centros de Cultura como espaços em que todos tivessem o direito de se expressar e expor suas ideias sobre os temas trazidos pela população" (p. 57). Deste modo, apresenta, ao leitor, de forma simples e objetiva, a finalidade ou objetivo central dos famosos círculos de cultura de Paulo Freire, o que certamente não é de conhecimento do grande público.

Apesar de instigante, a obra em análise não vai agradar a todos os seus leitores, especialmente àqueles que esperam um trabalho de natureza estritamente acadêmica ou científica; mas, certamente, merece ser lido como uma introdução às ideias de Paulo Freire, já que apresenta, com clareza e correção, os principais aspectos de sua vida e obra.

Portanto, trata-se de livro relevante que, por um lado, contribuirá para disseminação das concepções de Paulo Freire no seio social e, por outro, combaterá os estigmas e preconceitos que atualmente recaem sobre o Patrono da Educação Brasileira. 